\title{
Model latihan penyerangan (set plays) melalui goal throws dan powerplay futsal sekolah menengah atas
}

\author{
Pasha Erik Juntara*, Hari Amirullah Rachman \\ Program Studi Ilmu Keolahragaan, Program Pascasarjana, Universitas Negeri Yogyakarta. \\ Jalan Colombo No. 1, Karangmalang, Yogyakarta 55281, Indonesia \\ *Corresponding Author. Email: pasha_eyix@yahoo.com
}

\begin{abstract}
Abstrak
Penelitian ini bertujuan untuk menghasilkan model latihan penyerangan (set plays) melalui goal throws dan powerplay untuk peserta ekstrakurikuler futsal sekolah menengah atas yang layak digunakan. Penelitian pengembangan ini dilakukan dengan mengadaptasi langkah- langkah penelitian pengembangan menurut Borg \& Gall dengan beberapa modifikasi menjadi 7 tahap. Subjek uji coba dalam penelitian ini adalah peserta ekstrakurikuler futsal SMA Negeri 3 Bantul, SMK Tamansiswa Jetis Yogyakarta dan SMA Negeri 1 Pundong Bantul. Instrumen pengumpulan data yang digunakan yaitu pedoman wawancara, skala nilai, pedoman observasi model, lembar observasi efektivitas model dan kuesioner untuk siswa. Teknik analisis data yang dilakukan yaitu analisis deskriptif kuantitatif dan analisis deskriptif kualitatif. Hasil penelitian ini berupa model latihan penyerangan (set plays) melalui goal throws dan powerplay futsal sekolah menengah atas yang berisikan 12 pola penyerangan yaitu 8 pola penyerangan melalui goal throws dan 4 pola penyerangan dengan powerplay, yang disusun dalam bentuk buku panduan dan CD (compact disk). Hasil analisis data penilaian para ahli materi dan kuesioner siswa, dapat ditarik kesimpulan bahwa model latihan penyerangan (set plays) melalui goal throws dan powerplay futsal untuk sekolah menengah atas ini dinilai baik dan efektif, indeks kemampuan bermain hasil dari uji efektivitas produk juga mengalami peningkatan, dan respon peserta ekstrakurikuler futsal yang menjadi subjek dalam penelitian ini memberikan respon yang positif, sehingga model latihan yang dikembangkan layak untuk digunakan.
\end{abstract}

Kata kunci: model latihan; penyerangan; goal throws dan powerplay; futsal

\section{Attacking training model (set plays) through goal throws and powerplay of futsal senior high school}

\begin{abstract}
This study aimed to produce models of attacking training (set plays) through goal throws and powerplay for participants of high school's futsal extracurricular. This development research was conducted by adapting the research model proposed by Borg \& Gall which has been modified to became seven stages. The research subjects were members of futsal extracurricular activities in SMA Negeri 3 Bantul, SMK Tamansiswa Yogyakarta and SMA Negeri 1 Pundong. The data collection instruments used were interview guidelines, scale of scores, model observation guidelines, observation sheets of model effectiveness and questionnaires for the students. The data analysis techniques were descriptive quantitative analysis and descriptive qualitative analysis. Results of this research are a model of attacking training (set plays) through the goal throws and powerplay futsal at high school students containing twelve attacking patterns which are 8 attacking patterns through the goal throws and 4 patterns of attacking by powerplay, arranged in the form of a guide book and a CD (compact disk). Results of the data analysis materials expert judgments and students' questionnaire can be concluded that the model of attacking training (set plays) through the goal throws and powerplay of futsal for senior high school is considered good and effective, performance playing index of the results of the effectiveness test of the products also increased, and the response of futsal extracurricular participants sampled in this study gave a positive response, so that the developed training model deserves to be used.
\end{abstract}

Keywords: models of training; attacking; goal throws and powerplay; futsal 


\section{PENDAHULUAN}

Olahraga futsal saat ini menjadi salah satu pilihan yang favorit masyarakat untuk berolahraga. Futsal menjadi pilihan karena permainannya melibatkan banyak orang. Futsal tidak hanya dapat dimainkan orang dewasa saja, tetapi juga anak-anak. Futsal berkembang dengan cepat, hal ini ditandai dengan munculnya perkumpulan atau klub futsal dan sekolah futsal yang sudah mulai banyak didirikan diberbagai kota besar. Sekolah futsal menjadi sarana untuk mengembangkan bakat para pemain futsal sejak dini. Pada satuan pendidikan, hampir setiap sekolah saat ini juga memiliki ekstrakurikuler futsal untuk peserta didiknya. Hal ini menjadi sarana bagi peserta didik untuk mengembangkan bakat dan kemampuannya dalam bermain futsal.

Futsal dan sepakbola berhubungan sangat erat dan dekat, namun keduanya sebenarnya memiliki karakteristik permainan yang berbeda. Menurut Suharjanto (Marhaendro et al., 2009, p.145) direktur teknik dan pembinaan Badan Futsal Nasional (BFN), futsal saat ini sangat kental dengan nuansa sepakbola sebab hampir semua bentuk latihan dan prinsip bermain relatif sama dengan sepakbola, padahal futsal memiliki bentuk dan ukuran lapangan yang relatif berbeda dari sepakbola. Lapangan futsal jauh lebih sempit dan permukaan lapangan yang berbeda tekstur, ukuran gawang yang relatif lebih kecil, bola yang relatif kecil dan jenis pantulan yang berbeda, bahkan jumlah pemain relatif lebih sedikit, serta peraturan-peraturan permainan yang relatif jauh berbeda, maka dapat dikatakan tidak serta merta pemain sepakbola mampu beradaptasi dalam permainan futsal. Dengan perbedaanperbedaan karakteristik permainan dan peraturan yang digunakan, maka sangat logis jika dibutuhkan strategi dan teknik-teknik khusus yang mendukung permainan futsal.

Olahraga futsal termasuk dalam olahraga tim. Prestasi sebuah tim terbentuk dari hasil koordinasi dan kerja sama antar individu. Tenang (2008, p.87) mengemukakan bahwa dalam permainan olahraga apapun, kerjasama tim atau teamwork sangat penting sehingga selalu diutamakan. Kerja sama sebuah tim dapat berjalan apabila didukung kemampuan dan keterampilan tertentu dari setiap individu. Sehingga permainan futsal menuntut teknik penguasaan bola tinggi, kerjasama antar pemain, dan kekompakan tim (Wijayanti \& Kushartanti, 2014, p.36). Sesuai dengan tujuan futsal yaitu mencetak gol sebanyak-banyaknya ke gawang lawan, maka strategi penyerangan yang efektif akan sangat diperlukan dalam menghasilkan sebuah gol.

Berdasarkan hasil observasi dan wawancara (studi pendahuluan) yang dilakukan oleh peneliti pada beberapa ekstrakurikuler futsal sekolah menengah atas di Yogyakarta terungkap beberapa permasalahan yang dihadapi oleh pelatih dan peserta ekstrakurikuler futsal terkait dengan kegiatan ekstrakurikuler futsal. Masalah pertama yang dihadapi oleh peserta ekstrakurikuler futsal yaitu sedikitnya waktu latihan ekstrakurikuler futsal karena terlalu banyaknya ekstrakurikuler yang lain di sekolah menengah atas. Masalah kedua yang dihadapi pada pelaksanaan ekstrakurikuler futsal di sekolah menengah atas pelatih kurang memberikan bentuk-bentuk latihan yang bervariatif. Lebih lanjut pelatih belum memberikan model-model latihan penyerangan yang variatif dan efektif kepada peserta ekstrakurikuler futsal. Bahkan berdasarkan studi pendahuluan yang dilakukan, pelatih tidak pernah sekalipun memberikan latihan penyerangan powerplay. Padahal dalam futsal sekarang ini powerplay harus dilatihkan untuk dapat mengejar ketertinggalan ketika skor tim kita tertinggal dan waktu pertandingan semakin sedikit.

Terkait dengan kemampuan strategi penyerangan peserta ekstrakurikuler futsal sendiri ditemukan beberapa masalah pemahaman dari segi tingkat penguasaan variasi penyerangan tersebut. Terdapat beberapa kekurangan yang perlu diperbaiki dari cara bermain mereka salah satunya yaitu kemampuan menyerang dalam bermain futsal. Mereka kurang terlatih dalam pengorganisasian penyerangan, kebanyakan mereka belum paham dengan variasi penyerangan dalam futsal terutama dalam situasional tertentu. Selama ini pelatih lebih menekankan pada latihan teknik, fisik dan mental. Sedangkan latihan strategi jarang diberikan terutama pada strategi penyerangan dalam permainan futsal. Hal ini akan berakibat kurang pahamnya pemain terhadap hal apa yang harus dilakukan terlebih pada situasional yang berubah-ubah yang terjadi di dalam sebuah pertandingan. Padahal prestasi pemain futsal tidak terlepas dari peranan seorang pelatih. Pelatih harus jeli dalam menentukan strategi permainan, seperti halnya pemain yang berada di lapangan. Salah satu syarat untuk dapat membaca jalannya suatu pertandingan adalah saat pelatih harus mampu melihat "situasi futsal" dengan segala masalah yang ada pada situasi tersebut (Lhaksana, 2011, p.57). 
Lebih lanjut dari pengamatan/ observasi yang dilakukan pada Pocari Sweat Futsal Championship tingkat SMA di Provinsi Yogyakarta, peneliti melihat para pemain sering bingung dalam menerapkan pola penyerangan untuk membongkar pertahanan lawan terutama apabila lawan menerapkan pertahanan dengan sistem man to man defense. Pemain merasa panik dan kurang percaya diri serta tidak dapat keluar dari situasi ketika mereka ditekan. Padahal olahraga futsal membentuk seorang pemain agar selalu siap menerima dan mengumpan bola dengan cepat dalam tekanan pemain lawan (Wijayanti \& Kushartanti, 2014, p.35). Keadaan yang berbeda juga menunjukkan, apabila lawan menerapkan pertahanan dengan sistem zone defense pemain tidak bisa memanfaatkan kemampuan penjaga gawang untuk membantu penyerangan. Bahkan berdasarkan pengamatan peneliti hampir seluruh sekolah menengah atas yang mengikuti Pocari Sweat Futsal Championship regional Yogyakarta tidak pernah melakukan powerplay ketika tim mereka tertinggal dari lawan dan waktu pertandingan semakin sedikit. Untuk diketahui dalam permainan futsal sekarang ini, penjaga gawang dituntut mampu berperan dalam proses penyerangan terutama ketika tim dalam keadaan tertinggal dan waktu semakin sedikit. Dengan kata lain penjaga gawang harus menjadi goalplayer tidak hanya goalkeeper (Hermans, 2011, p.153).

Dalam futsal keterampilan teknik masing-masing pemain merupakan modal untuk menampilkan keterampilan taktik dan mental. Pemain dapat memiliki mental yang stabil apabila sudah memiliki penguasaan teknik yang lengkap, sehingga teknik individu merupakan keterampilan dasar dalam bermain futsal. Komponen teknik dalam bermain futsal dikelompokkan menjadi gerakan menggunakan bola dan tanpa bola. Selain itu dalam futsal ada beberapa aspek dasar yang menjadi komponen dari pola penyerangan dan pertahanan, menurut Jaya. A (2008, p.72) diantaranya adalah penguasaan terhadap bola, komposisi pemain, dan pola formasi permainan futsal.

Berdasarkan hasil temuan observasi tersebut ditemukan permasalahan yaitu model latihan penyerangan futsal yang diterima oleh peserta ekstrakurikuler futsal sekolah menengah atas di Yogyakarta belum sesuai dengan permainan saat di lapangan atau masih kurang sesuai dengan kondisi saat bertanding. Hal ini disebabkan kurangnya bentuk latihan penyerangan variatif yang diberikan pelatih kepada peserta ekstrakurikuler futsal sekolah menengah atas untuk diterapkan pada pertandingan yang sesungguhnya. Sehingga peneliti ingin mengembangkan model latihan penyerangan (set plays) melalui goal throws dan powerplay pada ekstrakurikuler futsal sekolah menengah atas di Yogyakarta.

Model latihan yang dikembangkan yaitu bagaimana memanfaatkan peran penjaga gawang dalam memulai penyerangan ketika lawan melakukan sistem pertahanan tertentu. Hal ini dikarenakan dalam sebuah permainan untuk memulai serangan salah satunya adalah melalui lemparan penjaga gawang (goal throws). Selain itu penjaga gawang juga dapat berperan dalam sebuah serangan ketika tim dalam keadaan tertinggal, atau dalam permainan futsal sering disebut dengan powerplay. Powerplay adalah sistem yang dilakukan pada saat sebuah tim ingin menyerang dengan 1 pemain atau lebih, dalam hal ini penjaga gawang ikut membantu penyerangan. Dalam futsal, peran penjaga gawang tidak hanya bertugas untuk mengamankan gawang. Penjaga gawang juga dituntut untuk berpartisipasi menyerang sebagai pemain kelima (Lhaksana \& Pardosi, 2008, p.37).

Model yang dikembangkan merupakan bentuk atau pola pergerakannya, yaitu bagaimana pemain menempatkan posisi dan melakukan pergerakan dengan atau tanpa bola selain juga bagaimana pemain dapat membuka ruang dalam melakukan penyerangan karena hal ini perlu dilatih ketika latihan. Dengan bekal latihan yang ajeg, progresif, dan komprehensif, diharapkan bentuk pola bermain akan menjadi gerak yang otomatis (Sukadiyanto, 2005, p.270). Oleh karena itu dalam permainan futsal dikenal dengan istilah set plays, yaitu permainan yang direncanakan. Dengan adanya model latihan penyerangan (set plays) melalui goal throws dan powerplay futsal, harapannya peserta bisa antusias menjalani latihan, dapat keluar dari tekanan lawan serta mampu menerapkan penyerangan futsal yang terorganisir dengan baik dan efektif, sehingga memperbesar peluang untuk menghasilkan gol dalam setiap pertandingan. Pada akhirnya model latihan penyerangan (set plays) melalui goal throws dan powerplay yang dikembangkan ini diharapkan dapat meningkatkan indeks kemampuan bermain peserta ekstrakurikuler futsal di sekolah menengah atas.

\section{METODE}

Penelitian ini merupakan penelitian dengan metode penelitian dan pengembangan atau sering disebut R\&D (Research and Development). Metode penelitian dan pengembangan adalah metode 
penelitian yang digunakan untuk menghasilkan produk tertentu, dan menguji keefektifan produk tersebut (Sugiyono, 2011, p.297). Dalam penelitian ini pengembangan dilakukan untuk mengembangkan sebuah model latihan penyerangan (set plays) melalui goal throws dan powerplay yang dapat digunakan untuk variasi latihan pada ekstrakurikuler futsal khususnya sekolah menengah atas dan kemudian dikemas dalam bentuk buku dan video panduan.

Prosedur pengembangan dalam penelitian ini sesuai dengan langkah-langkah penelitian pengembangan menurut Borg dan Gall. Menurut Borg dan Gall (2003, p.569), model penelitian dan pengembangan memiliki sepuluh langkah pelaksanaan penelitian langkah-langkah tersebut antara lain : (1) studi pendahuluan dan pengumpulan data (kajian pustaka, pengamatan lapangan, membuat kerangka kerja penelitian), (2) perencanaan (tujuan penelitian, dana, waktu, prosedur penelitian, berbagai bentuk partisipasi, (3) mengembangkan produk awal (perencanaan draft awal produk), (4) ujicoba awal (mencoba draft produk ke wilayah dan subjek yang terbatas), (5) revisi untuk menyusun produk utama, (6) uji coba lapangan utama (uji coba ke wilayah dan subjek yang lebih luas), (7) revisi untuk menyusun produk operasional, (8) uji coba produk operasional (uji efektif produk), (9) revisi produk final (revisi produk yang efektif), dan (10) diseminasi dan implementasi produk hasil pengembangan. Langkah-langkah tersebut diadaptasi menjadi tujuh rancangan prosedur penelitian pengembangan berikut ini:

Pengumpulan Informasi

Peneliti melakukan observasi untuk mengungkap lebih lanjut tentang kegiatan ekstrakurikuler futsal pada SMA dan SMK di Yogyakarta, yaitu SMA Negeri 3 Bantul, SMA Negeri 1 Pundong, dan SMK Tamansiswa Jetis Yogyakarta. Peneliti melakukan investigasi lebih mendalam terhadap pelaksanaan kegiatan ekstrakurikuler futsal ketiga sekolah untuk menghasilkan banyak informasi yang bermanfaat bagi peneliti. Peneliti ingin mengetahui masalah yang ada pada kegiatan ekstrakurikuler futsal. Berdasarkan hal tersebut peneliti melakukan wawancara sekilas pada guru di sekolah yang melatih kegiatan ekstrakurikuler futsal tersebut mengenai kemampuan peserta ekstrakurikuler futsal dalam menerapkan strategi penyerangan serta kendala yang dihadapi pada saat latihan. Proses selanjutnya, dilakukan pengumpulan informasi lebih lanjut dengan melakukan studi pendahuluan dengan cara studi pustaka. Hal yang dilakukan dalam studi pustaka yaitu mengumpulkan bahan mengenai teori-teori, data, dan hasil penelitian yang terkait dengan penelitian.

\section{Analisis Informasi}

Analisis dilakukan terhadap hasil studi pustaka dan wawancara. Analisis studi pustaka digunakan untuk memperkuat dalam fokus masalah yang sedang dikaji. Analisis wawancara dilakukan untuk mengetahui kebenaran asumsi peneliti dari kondisi nyata di lapangan mengenai permasalahan yang ada. Selanjutnya, disimpulkan mengenai permasalahan yang dihadapi guru ekstrakurikuler dalam kegiatan ekstrakurikuler futsal di SMA/SMK.

\section{Pengembangan Produk Awal}

Setelah proses analisis, peneliti mulai menyusun dan menciptakan suatu model guna membantu pelatih atau guru ekstrakurikuler futsal untuk mengatasi permasalahan yang ditemui dalam kegiatan ekstrakurikuler futsal. Produk pengembangan masih berupa produk awal dan dalam pengembangannya dilakukan hal-hal sebagai berikut: (a) menganalisis materi futsal yang dilakukan dalam latihan ekstrakurikuler futsal untuk siswa sekolah menengah atas, (b) menganalisis teknik dasar futsal, (c) menganalisis karakteristik siswa sekolah menengah atas, (d) menganalisis tujuan pengembangan model latihan penyerangan (set plays) melalui goal throws dan powerplay pada siswa sekolah menengah atas, (e) mengembangkan model latihan penyerangan (set plays) melalui goal throws dan powerplay pada siswa sekolah menengah atas.

\section{Validasi Ahli dan Revisi}

Sebelum dilakukan uji coba skala kecil terhadap produk awal, produk harus mendapat validasi dari ahli materi, yaitu: (a) pakar permainan dan olahraga, (b) pakar futsal, dan (c) praktisi futsal (guru/pelatih futsal). Pakar bidang permainan dan olahraga dalam penelitian ini yaitu Dr. Pamuji Sukoco, M.Pd., pakar futsal yaitu Saryono, M.Or., dan praktisi dibidang futsal seorang guru sekaligus merangkap pelatih yaitu Satriya Wicaksana, S.Or. Tujuan validasi dari ahli adalah untuk mendapatkan 
pengesahan terhadap model latihan penyerangan (set plays) melalui goal throws dan powerplay, serta mendapatkan masukan dan saran terhadap draf produk/model latihan yang dihasilkan.

\section{Uji Coba Skala Kecil dan Revisi}

Uji coba lapangan skala kecil akan didokumentasikan kedalam sebuah Digital Versatile Disc (DVD) yang kemudian akan dinilai oleh para ahli menggunakan panduan evaluasi berupa angket/kuesioner. Evaluasi yang dilakukan meliputi bentuk gerakan latihan penyerangan dan draf panduan model latihan penyerangan (set plays) melalui goal throws dan powerplay pada ekstrakurikuler futsal khususnya untuk sekolah menengah atas. Saran dan kritik yang diberikan oleh ahli akan ditindaklanjuti dengan melakukan revisi produk, selain itu saran dari pelatih juga akan dipertimbangkan guna mengembangkan produk.

\section{Uji Coba Skala Besar dan Revisi}

Tidak ada yang berbeda dalam uji coba lapangan kecil dan lapangan besar secara keseluruhan, namun perbedaan signifikan terletak pada jumlah subjek coba pada uji skala besar lebih banyak dan produk model latihan penyerangan (set plays) melalui goal throws dan powerplay pada ekstrakurikuler futsal sekolah menengah atas telah mengalami revisi.

Produk Akhir

Setelah melalui berbagai proses revisi, dilakukan penyusunan dan pembuatan produk akhir berupa buku dan video panduan model latihan penyerangan (set plays) melalui goal throws dan powerplay pada ekstrakurikuler futsal Sekolah Menengah Atas. Tahap ini bertujuan supaya produk yang baru saja dikembangkan itu bisa dipakai masyarakat luas (Ghufron, Purbani \& Sumardiningsih, 2007, p.16).

\section{Uji Coba Produk}

Uji coba produk dilakukan untuk mendapatkan data yang akan digunakan untuk mengetahui kelemahan-kelemahan produk yang dikembangkan sebagai dasar untuk melakukan revisi produk yang berupa model latihan penyerangan (set plays) melalui goal throws dan powerplay pada ekstrakurikuler futsal sekolah menengah atas. Uji coba kualitas model yang dikembangkan benar-benar telah teruji secara empiris, berikut penjabaran mengenai desain uji coba dan subjek uji coba.

Desain Uji Coba

Dalam penelitian ini uji coba produk awal (draft) awal dilakukan sebanyak dua kali, yaitu uji coba skala kecil kemudian dilanjutkan dengan uji coba skala besar. Pada uji coba skala kecil dan uji coba skala besar produk penelitian yang digunakan adalah sama yaitu berupa model latihan penyerangan (set plays) melalui goal throws dan powerplay. Dalam tahap/langkah pengembangannya melewati validasi dan revisi. Dari pengajuan draf model awal, uji coba skala kecil dan uji coba skala besar. Semua kegiatan uji coba wajib divalidasi terlebih dahulu kepada para pakar yang sudah ahli dibidangnya, dalam tahap tersebut selain validasi para pakar juga akan diberikan penilaian terhadap draf model yang telah disusun, sehingga akan diketahui apakah model yang disusun layak untuk diujicobakan di lapangan. Dalam tahap uji coba di lapangan peran dari para ahli materi adalah untuk mengobservasi kelayakan draf model yang telah disusun dengan kenyataan di lapangan.

Subjek Coba

Subjek coba dalam penelitian ini adalah siswa SMA/SMK putra yang mengikuti kegiatan ekstrakurikuler futsal. Dalam penelitian ini dilakukan uji coba model di lapangan, yaitu uji coba model skala kecil dan besar (Sudjana, 2005, p.163). Untuk uji coba skala kecil melibatkan 15 peserta ekstrakurikuler futsal SMA Negeri 3 Bantul dan uji coba skala besar melibatkan 30 peserta ekstrakurikuler futsal dari SMA Negeri 1 Pundong Bantul dan SMK Tamansiswa Jetis Yogyakarta.

\section{Instrumen Pengumpulan Data}

Wawancara

Wawancara dipakai dalam tahapan studi pendahuluan yaitu tahapan untuk mengumpulkan informasi. Teknik yang digunakan yaitu teknik komunikasi langsung dengan menggunakan instrumen 


\section{JORPRES (Jurnal Olahraga Prestasi), 15 (1), 2019 - 41}

Pasha Erik Juntara, Hari Amirullah Rachman

wawancara sebagai alat pengumpul data. Wawancara yang dilakukan yaitu wawancara bebas terpimpin, di mana pedoman wawancara digunakan sebagai pegangan pewawancara dalam mewawancarai responden. Pedoman wawancara tidak berbentuk seperangkat pertanyaan, namun hanya berbentuk butir-butir pertanyaan yang perlu disampaikan, yang disusun berdasarkan masalah, sub masalah dan variabel penelitian. Pewawancara menyusun sendiri kalimat pertanyaan tentang butirbutir tersebut pada setiap responden. Pertanyaan yang disusun dalam pedoman wawancara disesuaikan dengan tujuan pelaksanaan wawancara yaitu untuk menggali proses latihan/ekstrakurikuler futsal dan masalah-masalah yang dihadapi pelatih terkait kegiatan/latihan ekstrakurikuler futsal, untuk mendukung latar belakang masalah penelitian.

\section{Skala Nilai}

Skala nilai digunakan pada tahapan validasi ahli dan revisi untuk menilai kelayakan model latihan penyerangan (set plays) melalui goal throws dan powerplay futsal yang dikembangkan sebelum pelaksanaan uji coba skala kecil. Setelah para ahli menilai bahwa latihan penyerangan futsal sudah sesuai dengan unsur-unsur dalam skala nilai, model latihan penyerangan (set plays) melalui goal throws dan powerplay futsal baru dapat diujicobakan dalam uji coba skala kecil. Dalam skala nilai, variabel dan tujuan penelitian diklasifikasikan secara rinci menjadi gejala-gejala dengan unsurunsurnya. Klasifikasi tersebut disusun ke bawah, sedangkan ke samping dicantumkan kategori sesuai dengan maksud/tujuan penelitian, antara lain berupa urutan kualitas data yang dikumpulkan.

Kategori yang dimaksud dalam skala penilaian dalam penelitian pengembangan ini adalah berupa skala yang terdiri dari empat kategori berskala, yaitu Sangat Sesuai, Sesuai, Cukup Sesuai dan Tidak Sesuai. Cara penggunaan skala nilai yaitu bilamana muncul gejala atau unsur-unsur seperti yang terdapat dalam klasifikasi data, para ahli dan praktisi memberikan tanda cek $(\sqrt{ })$ pada kolom kategori. Apabila gejala atau unsur-unsur seperti yang terdapat dalam klasifikasi data yang dinyatakan sangat sesuai maka nilainya empat (4), apabila dinyatakan sesuai maka nilaianya tiga (3), apabila dinyatakan cukup sesuai maka nilaianya dua (2), dan apabila dinyatakan tidak sesuai maka nilainya satu (1).

\section{Instrumen Observasi}

Observasi merupakan cara mengumpulkan data yang dilakukan melalui pengamatan, dengan pengamatan terdapat kemungkinan untuk mencatat hal-hal, perilaku, pertumbuhan, dan sebagainya sewaktu kejadian tersebut berlangsung (Nazir, 2011, p.175). Observasi digunakan pada tahapan validasi ahli materi skala kecil dan skala besar serta revisi untuk mengetahui kelayakan model yang telah diujikan dalam skala kecil maupun skala besar. Teknik pengumpulan data yang digunakan dalam penelitian ini yaitu teknik observasi langsung dan tidak langsung dengan instrumen observasi berupa daftar cek (check list). Instrumen observasi langsung digunakan untuk mengumpulkan data awal pada waktu studi pendahuluan dan observasi tidak langsung digunakan untuk mengobservasi data setelah dilakukan di lapangan oleh ahli materi melalui tayangan video.

\section{Kuesioner Siswa}

Kuesioner siswa digunakan untuk mengetahui respon dari peserta didik terhadap produk model yang dikembangkan. Format penilaian akan memudahkan guru/pelatih dalam mengevaluasi penampilan siswa dan ketercapaian indikator yang diharapkan lewat latihan pola penyerangan futsal.

Instrumen Efektivitas Produk

Penelitian ini tidak hanya menghasilkan sebuah produk saja tetapi juga menguji keefektifan dari produk yang telah dihasilkan. Uji efektivitas produk akhir dilakukan menggunakan instrumen lembar observasi GPAI (Game Performance Assessment Instrument). Efektivitas produk akhir dikumpulkan melalui observasi langsung pada saat peserta melaksanakan sebuah pertandingan yang telah dikondisikan. GPAI digunakan untuk menilai gerakan dan keputusan yang dilakukan pemain selama latihan permainan yang dimodifikasi, yang mana peraturan, tempat, waktu dan peralatan telah disesuaikan, berdasarkan keterampilan pemain (Villora et al, 2015, p.3).

Penilaian kemampuan bermain adalah sebuah penilaian unjuk kerja yang bertujuan untuk mengetahui indeks kemampuan bermain peserta dalam melakukan penyerangan dalam permainan futsal. Dalam uji efektivitas ini data yang hendak dikumpulkan adalah hasil kemampuan masing- 
masing peserta ekstrakurikuler dalam melakukan penyerangan futsal dengan kecakapan dan keterampilan bermain terhadap sasaran yang telah ditentukan.

\section{Teknik Analisis Data}

Teknik analisis data yang dilakukan dalam penelitian ini yaitu analisis deskriptif kuantitatif dan analisis deskriptif kualitatif. Analisis deskriptif kuantitatif dilakukan untuk menganalisis data-data berikut: (1) data skala nilai hasil penilaian para ahli materi terhadap draft model latihan penyerangan (set plays) melalui goal throws dan powerplay sebelum pelaksanaan uji coba di lapangan, (2) data hasil observasi para ahli materi terhadap model latihan penyerangan (set plays) melalui goal throws dan powerplay, dan (3) data hasil observasi para ahli materi terhadap keefektifan model latihan penyerangan (set plays) melalui goal throws dan powerplay. Sementara analisis deskriptif kualitatif dilakukan terhadap: (1) data hasil wawancara dengan pelatih saat studi pendahuluan, (2) data kekurangan dan masukan terhadap model latihan penyerangan (set plays) melalui goal throws dan powerplay baik sebelum uji coba maupun setelah uji coba di lapangan.

Draf awal model latihan penyerangan (set plays) melalui goal throws dan powerplay dianggap layak untuk diujicobakan dalam skala kecil apabila para ahli materi telah memberi validasi dan menyatakan minimal tingkat validitas yang dicapai kategori sesuai. Mardapi (2008, p.123) menyatakan bahwa model latihan yang dikembangkan dikatakan valid, jika minimal tingkat validitas yang dicapai adalah masuk dalam kategori baik. Dalam hal ini terdapat empat jenis nilai, yaitu hasil penilaian "sangat sesuai" mendapat nilai empat (4) "sesuai" mendapat nilai tiga (3) "cukup sesuai" mendapat nilai dua (2) dan hasil penilaian "tidak sesuai" mendapat nilai satu (1). Jika terdapat ahli materi yang berpendapat bahwa item klasifikasi tidak sesuai (nilai satu), maka dilakukan pengkajian ulang terhadap model pengembangan yang dapat ditindaklanjuti dengan proses revisi.

Untuk data hasil observasi para ahli materi dan guru/pelatih pelaku uji coba terhadap model latihan penyerangan (set plays) melalui goal throws dan powerplay serta keefektifan model latihan penyerangan (set plays) melalui goal throws dan powerplay, terdapat empat jenis nilai yang terlebih dahulu ditentukan kriteria nilai dan batas-batasnya. Hasil penilaian terhadap item-item observasi dijumlahkan, lalu diambil rerata nilainya dikonversikan untuk mengetahui kategorinya. Pengkonversian nilai dilakukan dengan mengikuti standar Penilaian Acuan Patokan (PAP). Menurut Mardapi (2008, p.123) dalam menginterpretasikan skor mentah menjadi nilai dengan menggunakan pendekatan PAP, terlebih dahulu ditentukan kriteria nilai dan batas-batasnya. Karena berdasar skala yang dipakai dalam pengkorversian menggunakan skala empat maka yang pakai dalam perhitungan normatif menggunakan empat kategori yaitu tidak baik, cukup, baik, dan sangat baik yang akan dipaparkan pada Tabel 1.

Tabel 1. Perhitungan Normatif Kategorisasi

\begin{tabular}{ccc}
\hline & Interval & Kategori \\
\hline $\mathrm{X} \geq \overline{\mathrm{X}}+1$. Sbi & $\mathrm{X} \geq 3,0$ & Sangat Baik \\
$\overline{\mathrm{x}}+1 . \mathrm{SBi}>\mathrm{X} \geq \overline{\mathrm{X}}$ & $2,5 \leq \mathrm{X}<3,0$ & Baik \\
$\overline{\mathrm{x}}>\mathrm{X} \geq \overline{\mathrm{x}}-1$.Sbi & $2,0<\mathrm{X}<2,5$ & Cukup \\
$\mathrm{X}<\overline{\mathrm{x}}-1$.Sbi & $\mathrm{X} \leq 2,0$ & Tidak Baik \\
\hline
\end{tabular}

Perhitungan Normatif Kategorisasi menurut Mardapi (2008, p.123)

Keterangan:

$\overline{\mathrm{x}}=$ Rerata Skor deal $=\frac{1}{2}($ S.Maks ideal + S.Min ideal $)$

Simpangan Baku ideal $(\mathrm{Sbi})=\frac{1}{6}($ S.Maks ideal-S.Min ideal $)$

$\mathrm{X}=$ Perolehan skor

\section{HASIL DAN PEMBAHASAN}

\section{Hasil Pengembangan Produk Awal}

Analisis Kebutuhan

Sesuai dengan prosedur penelitian, hal yang pertama dilakukan adalah mengumpulkan hasil riset dan informasi, yaitu dengan melakukan analisis kebutuhan. Analisis kebutuhan dilakukan untuk mengetahui permasalahan yang terjadi di lapangan berkaitan dengan kegiatan ekstrakurikuler futsal di 
sekolah menengah atas (SMA). Peneliti melakukan observasi lapangan dalam kegiatan ekstrakurikuler futsal di beberapa SMA dan SMK Negeri maupun Swasta yang ada di Yogyakarta. Hasil observasi dan wawancara menunjukkan bahwa pemanfaatan model latihan terutama pola penyerangan dalam latihan ekstrakurikuler futsal belum terlaksana dengan maksimal bahkan beberapa sekolah tidak memiliki program latihan. Guru/pelatih hanya membiarkan siswa bermain sendiri tanpa adanya program yang jelas sehingga kemampuan siswa tidak bertambah baik. Secara otomatis prestasi siswa dalam kegiatan ekstrakurikuler futsal kurang baik. Proses latihan yang menyeluruh seharusnya diajarkan dengan tahapan yang runtut dan berkesinambungan dengan program latihan yang baik. Dalam konteks latihan tersebut seharusnya diberikan melalui latihan teori dan praktik yang baik.

Draf Awal

Draf awal model latihan penyerangan (set plays) melalui goal throws dan powerplay futsal pada siswa sekolah menengah atas (SMA) seluruhnya terdapat 12 model pola penyerangan, terdiri dari 8 model pola penyerangan melalui goal throws dan 4 model pola penyerangan powerplay. Model latihan ini disusun dengan menggabungkan teori mengenai teknik dasar futsal, gambar, video, dan bentuk latihan penyerangan.

\section{Data Validasi Ahli Materi}

Draf awal model latihan penyerangan (set plays) melalui goal throws dan powerplay futsal diajukan ke ahli materi. Draf model yang sudah mendapat validasi dari ahli materi boleh diujicobakan di lapangan. Sebelum mendapat validasi maka draf terlebih dahulu direvisi sesuai dengan arahan dan masukan dari ahli materi. Hasil dari revisi draf awal model permainan selanjutnya diajukan untuk mendapatkan validasi draf model. Berdasarkan penilaian dari para ahli materi terhadap skala nilai, terlihat bahwa total nilai draf awal model latihan penyerangan (set plays) melalui goal throws dan powerplay telah memenuhi persyaratan kelayakan untuk diujicobakan di lapangan.

\section{Data Uji Coba Skala Kecil}

Setelah mendapatkan validasi para ahli materi terhadap draf awal model latihan pola penyerangan (set plays) melalui goal throws dan powerplay, peneliti melakukan uji coba skala kecil di SMA Negeri 3 Bantul. Dari pelaksanaan uji coba skala kecil, didapatkan data dari ahli materi (ahli permainan, ahli futsal, dan pelatih ekstrakurikuler futsal SMA) meliputi: (1) data hasil observasi model latihan penyerangan (set plays) melalui goal throws dan powerplay, (2) data hasil observasi keefektifan model latihan penyerangan (set plays) melalui goal throws dan powerplay, (3) data masukan terhadap model latihan penyerangan (set plays) melalui goal throws dan powerplay. Selain itu didapatkan juga data respon dari siswa terhadap model latihan pola penyerangan (set plays) melalui goal throws dan powerplay.

\section{Data Uji Coba Skala Besar}

Setelah dilakukan uji coba skala kecil dan proses revisi terhadap draf model latihan penyerangan (set plays) melalui goal throws dan powerplay berdasarkan hasil observasi dan masukanmasukan dari ahli materi. Langkah selanjutnya peneliti melakukan uji coba skala besar di SMK Tamansiswa Jetis Yogyakarta dan SMA Negeri 1 Pundong. Dari pelaksanaan uji coba skala besar, didapatkan data dari ahli materi (ahli permainan, ahli futsal, dan guru/pelatih ektrakurikuler futsal SMA) meliputi: (1) data hasil observasi model latihan penyerangan (set plays) melalui goal throws dan powerplay, (2) data hasil observasi keefektifan model latihan penyerangan (set plays) melalui goal throws dan powerplay, (3) data masukan terhadap model latihan penyerangan (set plays) melalui goal throws dan powerplay. Selain itu didapatkan juga data respon dari siswa terhadap model latihan penyerangan (set plays) melalui goal throws dan powerplay.

\section{Hasil Uji Coba Produk}

\section{Analisis Data Validasi Ahli Materi}

Dari hasil penilaian skala nilai (Rating scale) yang diberikan pakar/ahli materi terhadap revisi draf awal model sebelum diujicobakan di lapangan, para ahli materi: (1) Pamuji Sukoco (ahli permainan), (2) Saryono (ahli futsal), dan (3) Satriya (pelatih ekstrakurikuler SMA) sependapat bahwa model latihan penyerangan (set plays) melalui goal throws dan powerplay futsal yang terdiri dari 12 


\section{JORPRES (Jurnal Olahraga Prestasi), 15 (1), 2019 - 44}

Pasha Erik Juntara, Hari Amirullah Rachman

model latihan pola penyerangan, yaitu 8 model latihan pola penyerangan melalui goal throws dan 4 model latihan pola penyerangan powerplay, yang dikembangkan dinilai telah "sesuai" dengan itemitem klasifikasi dalam penilaian skala nilai sehingga dinyatakan layak untuk diujicobakan di lapangan.

Analisis Data Uji Coba Skala Kecil

Dari penilaian ahli materi terhadap instrumen observasi pada uji coba skala kecil, para ahli materi sependapat bahwa model latihan penyerangan (set plays) melalui goal throws dan powerplay futsal yang terdiri dari 12 model latihan pola penyerangan, yaitu yaitu 8 model latihan pola penyerangan melalui goal throws dan 4 model latihan pola penyerangan powerplay yang dikembangkan termasuk dalam kategori baik dan efektif. Meskipun model latihan pola penyerangan sudah memenuhi item-item observasi, namun terdapat beberapa masukan dari para ahli materi yaitu sebaiknya pergerakan model dibuat seefektif mungkin dengan resiko yang kecil serta disarankan diberi animasi simulasi petunjuk praktis sebelum video. Menyikapi masukan dari para ahli materi terhadap model latihan yang dikembangkan, peneliti melakukan revisi untuk penyempurnaan produk lebih lanjut sebelum dilakukan uji coba skala besar.

Analisis Data Uji Coba Skala Besar

Dari penilaian ahli materi terhadap instrumen observasi pada uji coba skala besar, para ahli materi sependapat bahwa model latihan penyerangan (set plays) melalui goal throws dan powerplay futsal yang terdiri dari 12 model latihan penyerangan yang dikembangkan termasuk dalam kategori baik dan efektif. Berdasarkan hasil observasi dari ahli materi terhadap pelaksanaan uji coba skala besar model latihan pola penyerangan (set plays) melalui goal throws dan powerplay futsal, para ahli materi menganggap bahwa model yang dikembangkan sudah baik dan efektif, sehingga tidak ada masukan lagi atau tidak diperlukan perbaikan/revisi.

\section{Revisi Produk}

Revisi produk model latihan penyerangan (set plays) melalui goal throws dan powerplay futsal ini terdiri dari: (1) revisi draf produk awal, (2) revisi produk uji coba skala kecil, dan (3) revisi produk uji coba skala besar.

\section{Revisi Draf Awal Model}

Berdasarkan masukan dari para ahli materi, yaitu: (a) ahli materi pertama Pamuji Sukoco yaitu perlu diberikan penjelasan yang lebih spesifik tentang gambar dan instruksi pelaksanaan model latihan, (b) ahli materi kedua Saryono antara lain; pola penyerangan dalam permainan futsal harus variatif agar tidak mudah dibaca lawan dan dibuat dengan resiko sekecil mungkin.

\section{Revisi Produk setelah Uji Coba Skala Kecil}

Berdasarkan analisis data observasi dan masukan dari 3 ahli materi pada uji coba skala kecil, maka dilakukan revisi terhadap produk yang dikembangkan. Revisi/perbaikan produk yang dilakukan pada model latihan pola penyerangan (set plays) melalui goal throws dan powerplay futsal yang dikembangkan setelah uji coba skala kecil yang dilakukan yaitu: (a) pada gambar model latihan pola penyerangan tersebut seharusnya digambarkan lebih spesifik sehingga pergerakan setiap pemain lebih jelas, (b) perlunya simulasi petunjuk praktis berupa animasi.

\section{Revisi Produk setelah Uji Coba Skala Besar}

Berdasarkan analisis data dari ketiga ahli materi, revisi produk setelah uji coba skala besar tidak perlu dilakukan, karena para pakar/ahli materi mengangap bahwa model latihan pola penyerangan (set plays) melalui goal throws dan powerplay futsal yang terdiri dari 12 model pola penyerangan, yaitu 8 model latihan pola penyerangan melalui goal throws dan 4 model latihan pola penyerangan powerplay yang dikembangkan dianggap baik dan efektif serta layak untuk digunakan.

\section{Kajian Produk Akhir}

Setelah mendapat penilaian dan masukan dari 3 pakar/ahli materi, baik dari para ahli materi maupun pelatih ekstrakurikuler futsal kemudian dilakukan proses-proses revisi terhadap draf model latihan pola penyerangan yang dikembangkan. Akhirnya dihasilkan model latihan penyerangan (set 
plays) melalui goal throws dan powerplay futsal yang terdiri dari 12 model pola penyerangan, yaitu 8 model latihan pola penyerangan melalui goal throws dan 4 model latihan pola penyerangan powerplay, yang disusun dalam bentuk buku panduan dan dalam bentuk DVD (Digital Versatile Disc).

\section{Efektivitas Produk}

Penelitian pengembangan ini tidak hanya untuk menghasilkan produk penelitian saja, tetapi juga menguji efektivitas produk yang telah dihasilkan. Uji efektivitas dilakukan dalam 4 pertemuan dalam proses latihan ekstrakurikuler futsal. Dari hasil penilaian tahap awal dan hasil penilaian tahap akhir yang telah dilakukan terdapat perbedaan dari masing-masing indeks kemampuan bermain peserta. Hasil penilaian tahap awal indeks kemampuan bermain menunjukkan skor sebesar 15,24 dan hasil penilaian tahap akhir menunjukkan skor sebesar 18,81. Hasil tersebut menunjukkan bahwa ada peningkatan yang efektif terhadap indeks kemampuan bermain peserta ekstrakurikuler dengan menggunakan model latihan penyerangan (set plays) melalui goal throws dan powerplay yaitu sebesar $23,4 \%$. Adapun gambaran dari peningkatan efektivitas indeks secara keseluruhan model latihan penyerangan (set plays) melalui goal throws dan powerplay dapat dilihat pada diagram berikut.

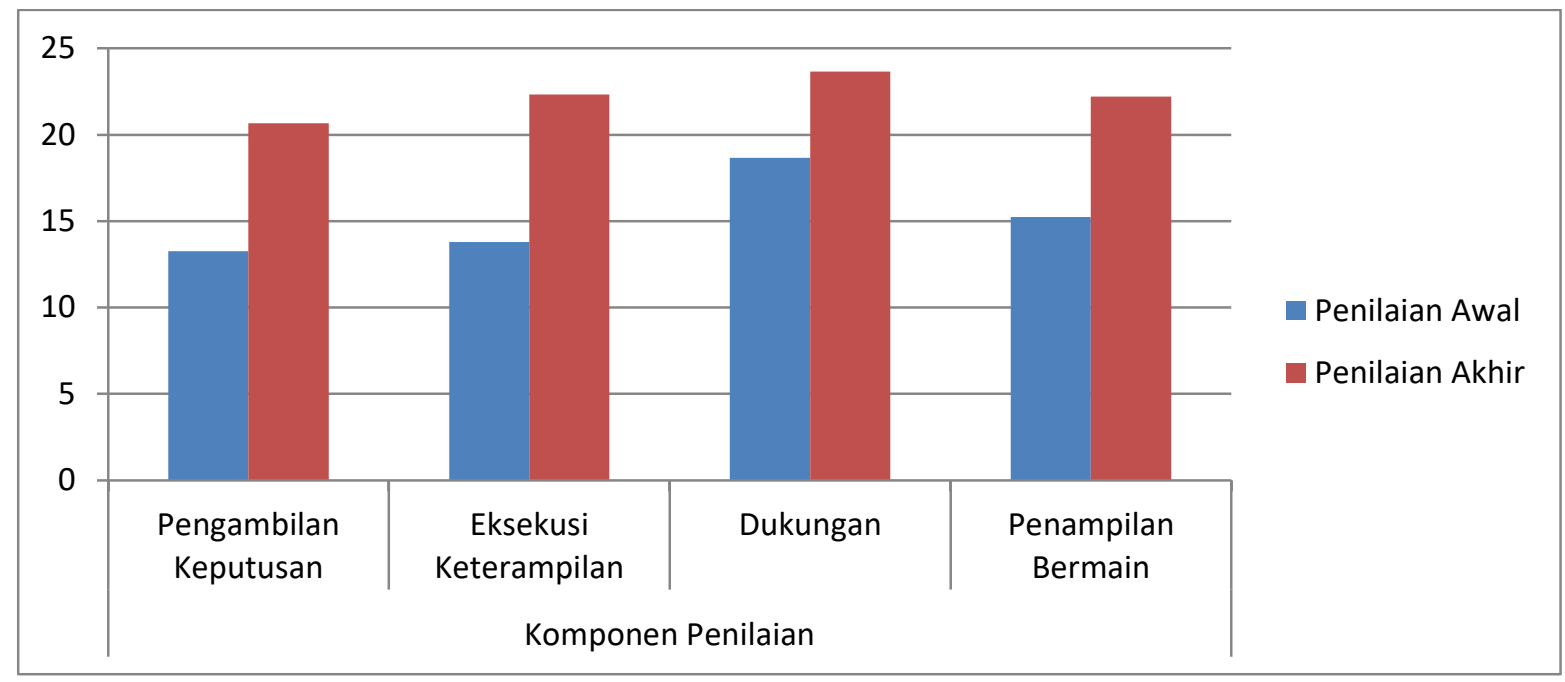

Gambar 1. Diagram Hasil Penilaian Uji Efektivitas

\section{SIMPULAN}

Hasil analisis data penilaian dari para ahli materi terhadap 12 model latihan penyerangan (set plays) melalui goal throws dan powerplay yang dikembangkan dapat disimpulkan bahwa 12 model latihan penyerangan (set plays) melalui goal throws dan powerplay untuk peserta ekstrakurikuler futsal sekolah menengah atas ini dinilai baik dan efektif. Berdasarkan hasil observasi dari ahli materi terhadap pelaksanaan uji coba skala kecil maupun besar, model latihan penyerangan (set plays) melalui goal throws dan powerplay yang dikembangkan sudah sesuai dengan kebutuhan peserta ekstrakurikuler futsal karena dapat meningkatkan keterampilan bermain peserta ekstrakurikuler futsal dan efektif meningkatkan proses kegiatan ekstrakurikuler di sekolah menengah atas. Sedangkan produk dari penelitian pengembangan ini berupa model latihan penyerangan (set plays) melalui goal throws dan powerplay untuk peserta ekstrakurikuler futsal sekolah menengah atas yang berisikan 12 pola penyerangan yaitu 8 pola penyerangan melalui goal throws dan 4 pola penyerangan powerplay, yang disusun dalam bentuk buku panduan dan dalam bentuk DVD (Digital Versatile Disc).

Berdasarkan hasil analisis terhadap peserta ekstrakurikuler yang menjadi sampel dalam penelitian ini, bahwa respon peserta ekstrakurikuler futsal SMA merasa senang melakukan latihan pola penyerangan (set plays) melalui goal throws dan powerplay yang diajarkan dan ingin melakukannya kembali di kegiatan ekstrakurikuler berikutnya, sehingga secara umum peserta ekstrakurikuler memberikan respon yang positif terhadap model latihan pola penyerangan (set plays) melalui goal throws dan powerplay. Oleh karena itu, dapat disimpulkan bahwa model latihan penyerangan (set plays) melalui goal throws dan powerplay yang dikembangkan layak untuk digunakan sebagai salah satu bentuk latihan dalam kegiatan ekstrakurikuler di SMA/SMK. 


\section{JORPRES (Jurnal Olahraga Prestasi), 15 (1), 2019 - 46}

Pasha Erik Juntara, Hari Amirullah Rachman

\section{DAFTAR PUSTAKA}

Borg, W.R., Gall, J.P., \& Gall, M.D. (2003). Educational research: An introduction. seventh edition. New York: Longman.

Ghufron, A., Purbani, W., \& Sumardiningsih, S. (2007). Panduan penelitian dan pengembangan. bidang pendidikan dan pembelajaran. Yogyakarta: Lembaga Penelitian Universitas Negeri Yogyakarta.

Hermans, Vic. (2011). Futsal, technique-tactics-training. UK: World sport publishers association.

Irawan, A. (2009). Teknik dasar modern futsal. Jakarta Pusat: Pena Pundi Aksara.

Jaya, A. (2008). Futsal gaya hidup, peraturan, dan tips-tips permainan. Yogyakarta: Pustaka Timur.

Lhaksana, J. (2011). Taktik dan strategi futsal modern. Depok: Be Champion.

Lhaksana, J \& Pardosi, I. H. (2008). Inspirasi dan spirit futsal. Depok: Raih Asa Sukses.

Mardapi, D. (2008). Teknik penyusunan instrumen tes dan non tes. Yogyakarta: Mitra Cendikia Press.

Marhaendro, A. S. D., Saryono, Yudanto. (2009). Tes keterampilan dasar bermain futsal. Jurnal Iptek Olahraga, 2, 144-156.

Nazir, M. (2011). Metode penelitian. Bogor: Ghalia Indonesia.

Sugiyono. (2011). Metode penelitian kuantitatif kualitatif dan R\&D. Bandung: Alfabeta.

Sukadiyanto \& Muluk, D. (2011). Pengantar teori dan metodologi melatih fisik. Bandung: Lubuk Agung.

Tenang, J. D. (2008). Mahir bermain futsal. Bandung: Dar Mizan.

Wijayanti, D., \& Kushartanti, B. (2014). Model tes keterampilan dasar futsal bagi pemain KU 10-12 tahun. Jurnal Keolahragaan, 2(1), 32 - 45. doi:https://doi.org/10.21831/jk.v2i1.2601 